\title{
MODEL MANAJEMEN SISTEM PENDUKUNG KEPUTUSAN \\ METODE SIMPLE ADDITIVE WEIGHTING (SAW) \\ UNTUK PROGRAM BANTUAN LANGSUNG \\ TUNAI DI DESA LUWUNGBATA
}

\author{
Rini Astuti 1 \\ Uum Mukaromah ${ }^{2}$ \\ Sekolah Tinggi Manajemen Informatika dan Komputer LIKMI \\ Jl. Ir. H. Juanda no 96 Bandung \\ 1 riniastuti@likmi.ac.id \\ 2 uummukaromah7@gmail.com
}

\begin{abstract}
ABSTRAK
Bantuan Langsung Tunai (cash transfers) atau disingkat BLT adalah program bantuan pemerintah berjenis pemberian uang tunai atau beragam bantuan lainnya, baik bersyarat (conditional cash transfer) maupun tak bersyarat (unconditional cash transfer) untuk masyarakat miskin. BLT di Desa Luwungbata tidak luput dari berbagai kendala seperti kurangnya evaluasi teradap warga sehingga mengakibatkan penyaluran dana bantuan langsung tunai tidak tepat sasaran. Penelitian ini menggunakan model manajemen metode Simple Additive Weighting (SAW) dengan menentukan kriteria-kriteria yang di jadikan acuan dalam pengambilan keputusan yaitu luas bangunan, jenis dinding, jenis lantai, fasilitas buang air, sumber penerangan, bahan bakar, makanan sehari-hari, pakaian, pengobatan dan pendidikan. Hasil proses analisis berupa data keluarga miskin yang berhak menerima BLT.

Untuk mengatasi masalah yang ada, diperlukan sebuah sistem yang dapat membantu pengambil keputusan untuk memntukan keluarga yang berhak menerima BLT dengan tepat oleh karena itu di penelitian ini dibangun sistem pendukung keputusan untuk pemberian BLT. Model manajemen sistem pendukung keputusan yang dipakai menggunakan metode SAW dengan bahasa pemrograman PHP dan database MySQL. Pendekatan proses pengembangan yang digunakan adalah pendekatan berorientasi objek dengan tool UML dengan model proses prototyping. Dengan adanya sistem pendukung keputusan ini, dapat mempermudah dan mempercepat pengolahan data serta mempengaruhi kinerja sehingga menjadi lebih optimal. Hasil yang diharapkan adalah tersedianya sistem pendukung keputusan menggunakan metode SAW yang dapat menentukan keluarga miskin yang berhak menerima Bantuan Langsung Tunai sehingga dana bantuan langsung tunai jatuh kepada keluarga yang benar-benar membutuhkan.
\end{abstract}

Kata Kunci : Sistem Pendukung Keputusan, Bantuan Langsung Tunai, SAW.

\section{PENDAHULUAN}

Sistem pendukung keputusan dapat membantu para pengambil keputusan memastikan alternatif solusi pemecahan masalah yang terbaik sesuai kebutuhan kasus permasalahan. Penelitan ini akan memfokuskan pada implementasi salah satu model 
sistem pendukung keputusan yaitu metode SAW untuk kasus pemberian Bantuan Tunai Langsung di Desa Luwungbata.

BLT merupakan tindakan yang diambil oleh pemerintah untuk memberikan subsidi kepada masyarakat yang membutuhkan di Indonesia. Turunnya bantun langsung tunai adalah karena adanya kenaikan harga bahan bakar minyak dan harga kebutuhan pokok yang terus meningkat. Penduduk desa Luwungbata terbagi menjadi tiga tingkatan yaitu keluarga tingkat atas, keluarga tingkat menengah dan keluarga tingat bawah. Desa Luwungbata dalam penentuan keluarga miskin hanya dengan menduga-duga atau memperkirakan dengan melihat kondisi perkenomian warga tersebut tanpa memperhitungkan berdasarkan ketentuan sehingga dana bantuan langsung tunai tidak jatuh kepada keluarga yang berhak dan benar-benar membutuhkan.

Sistem pendukung keputusan digunakan untuk membantu pengambilan keputusan dalam situasi terstruktur dan semi terstruktur. Sehingga pihak desa dapat menentukan keluarga miskin yang layak dan tidak layak untuk mendapatkan bantuan, dalam penelitian ini menggunakan metode SAW.

\subsection{RUANG LINGKUP}

Ruang lingkup dari penelitian yang dibahas adalah sebagai berikut :

a. Menganalisis kondisi Program Bantuan Langsung yang sedang berjalan.

b. Membangun Model manajemen Sistem pendukung keputusan dengan Metode SAW untuk mendukung pengambilan keputusan pemberian program Bantuan Langsung Tunai.

\subsection{TUJUAN PENELITIAN}

Tujuan dilaksanakannya penelitian adalah :

a. Merancang sistem pendukung keputusan dengan metode SAW dengan pendekatan berorientasi objek.

b. Menerapkan salah satu model sistem pendukung keputusan yaitu Metode SAW.

\section{LANDASAN TEORI}

\subsection{MODEL PROTOTYPING}

Perencanaan iterasi pembuatan prototipe dilakukan secara cepat. Setelah itu dilakukan pemodelan dalam bentuk "rancangan cepat". Pembuatan rancangan cepat berdasarkan pada representasi aspek- aspek perangkat lunak yang akan terlihat oleh para end user (misalnya rancangan antarmuka pengguna atau format tampilan). Rancangan cepat merupakan dasar untuk memulai konstruksi pembuatan prototipe.

Menurut Pressman [5], model prototyping dimulai dari tahap komunikasi. Tim pengembang melakukan pertemuan dengan para stakeholder untuk menentukan kebutuhan sistem yang saat itu diketahui dan untuk menggambarkan area-area dimana definisi kebutuhan ditentukan untuk iterasi selanjutnya.

Prototipe kemudian diserahkan kepada para stakeholder untuk mengevaluasi prototype yang telah dibuat sebelumnya dan memberikan umpan-balik yang akan digunakan untuk memperbaiki spesifikasi kebutuhan. Iterasi terjadi saat pengembang melakukan perbaikan terhadap prototipe tersebut.

\subsection{SISTEM PENDUKUNG KEPUTUSAN}

Sistem pendukung keputusan merupakan sebuah sistem yang sistematis dalam pengambilan keputusan karena memiliki pendekatan yang teratur dan terarah. Untuk menghasilkan tujuan yang jelas, langkah-langkah dalam pengambilan keputusan melalui 
metode atau cara yang sistematis sehingga diperoleh suatu keputusan yang tepat dalam menyelesaikan sebuah masalah (Dermawan, 2013).

Sistem pendukung keputusan berbasis komputer merupakan sumber daya manusia yang dapat memecahkan sebuah permasalahan atau memperbaiki keputusan dalam lingkungan manajemen yang mengalami masalah terstruktur (Ananta, 2013).

\subsection{METODE SAW}

Menurut Frieyadie dalam jurnalnya menerangkan bahwa "Metode Simple Additive Weighting adalah mencari penjumlahan terbobot dari rating kinerja pada setiap alternatif pada semua atribut" (Frieyadie, 2016)

Langkah-langkah perhitungan mengambil keputusan :

a. Menentukan kriteria-kriteria yang akan dijdikan acuan dalam pengambiln keputusan yaitu Ci.

b. Menentukan rating kecocokan setiap alternatif pada setiap kriteria.

c. Membuat matriks keputusan berdasarkan kriteria (Ci).

d. Normalisasi kriteria benefit atau keuntunganmengunakan rumusan : $\mathrm{Rii}=(\mathrm{Xij} / \max \{\mathrm{Xij}\})$

e. Normalisasi kriteria cost atau biaya menggunakan rumusan : $\mathrm{Rii}=(\min \{\mathrm{Xij}\} / \mathrm{Xij})$

f. Masukan semua hasil perhitungan kedalam vektor ternormalisasi R.

g. Mengalikan setiap kolom ditebel tersebut dengan bobot kriteria yang telah di deklarasikan.

h. Hasil akhir diperoleh dari proses perankingan yaitu penjumlahan dari perkalian matriks ternormalisasi $\mathrm{R}$ dengan vektor bobot sehingga diperoleh nilai terbesar yang dipilih sebagai alternatif terbaik (Ai) sebagai solusi.

Adapun kelebihan metode SAW menurut Landung Sudarmana dan Wakhid Sulthani Aziz Komara Putra yaitu sebagai berikut :

a. Dapat menentukan nilai bobot untuk setiap atribut, kemudian dilanjutkan dengan proses perangkingan yang akan menyeleksi alternatif terbaik dari sejumlah alternatif.

b. Penilaian akan lebih tepat karena didasarkan pada nilai kriteria dan bobot preferensi yang sudah ditentukan (Sudarmana \& Putra, 2017).

\subsection{BANTUAN LANGSUNG TUNAI}

Menurut Wiwin Wijayanti, Kustanto, Sri Tomo dalam jurnalnya menerangkan bahwa "Bantuan Langsung Tunai adalah suatu bentuk bantuan dari pemerintah sebagai bentuk kompensasi dari kenaikan harga Bahan Bakar Minyak (BBM), yang tentunya mengimbas kepada kehidupan masyarakat luas termasuk kalangan masyarakat miskin". (Wijayanti, Kustanto, \& Tomo, 2013)

Program BLT dilaksanakan melalui koordinasi lintas sektoral yang bekerja sama berdasarkan fungsi dan tugas pokok masing-masing lembaga. Sebagaimana disebutkan dalam Inpres No. 3 Tahun 2008 yang menjadi dasar hukum pelaksanaan Program BLT 2008, penanggung jawab penyaluran dana BLT adalah Depsos yang bekerja sama dengan berbagai instansi pemerintah terkait. Melalui Kepmensos No.28/HUK/2008, Menteri Sosial menunjuk PT Pos Indonesia dan BRI sebagai pelaksana penyaluran dana BLT 2008 kepada RTS/Rumah Tangga Sasaran (Lembaga Penelitian SMERU).

Selain itu dalam rangka melindungi masyarakat miskin, pemerintah memperluas Jaring Pengaman Sosial (JPS) termasuk yang tertuang dalam Peraturan Menteri Desa PDTT Nomor 6 Tahun 2020 tentang Perubahan Peraturan Menteri Desa PDTT Nomor 11 Tahun 2019 tentang Prioritas Penggunaan Dana Desa yang diantaranya terkait 
penyediaan Bantuan Langsung Tunai yang bersumber dari Dana Desa (BLTDana Desa).

Dalam rangka melancarkan pelaksanaan BLT-Dana Desa ini berbagai kebijakan lain telah diterbitkan diantaranya adalah Instruksi Menteri Dalam Negeri Nomor 3 Tahun 2020 tentang Penanggulangan COVID-19 Di Desa Melalui Anggaran Pendapatan dan Belanja Desa dan Peraturan Menteri Keuangan Nomor 40 Tahun 2020 tentang Perubahan Atas Peraturan Menteri Keuangan Nomor 205 Tahun 2019 tentang Pengelolaan Dana Desa (Kementerian PPN/Bappenas 2020).

\section{METODOLOGI DAN PEMBAHASAN \\ 3.1 METODOLOGI}

Penelitian ini merupakan penelitian kualitatif dan kuantitatif yang akan mencoba mengimplementasikan metode Simple Addtitive Weighting untuk melakukan proses penilaian dan pemilihan keluarga miskin yang berhak menerima bantuan langsung tunai, dengan tujuan meminimalisir penilaian subjektif dan supaya dana bantuan langsung tunai bisa tepat sasaran sampai kepada keluarga miskin yang membutuhkan. Adapun tahapantahapan yang dilakukan dalam penelitian ini adalah :

Adapun tahapan-tahapan yang dilakukan dalam penelitian ini adalah :

a. Analisis dan evaluasi di lapangan

Analisis dan evaluasi dilakukan dengan mendatangi langsung tempat penelitian, peneliti melakukan observasi, wawancara dengan salah satu staff Desa Luwungbata untuk mengetahui masalah yang ada dan sedang dihadapi ditempat penelitian yang diperlukan sebagai bahan studi pusaka untuk mengambil data-data yang dapat mendukung penelitian.

b. Pengumpulan data pendukung penelitian

Pengumpulan data pendukung penelitian dilakukan dengan mengumpulkan dokumen internal maupun eksternal sebagai dasar dilakukannya penelitian, supaya mendapatkan data-data yang akan dijadikan sebagai dasar dilakukannya penelitian.

c. Perancangan sistem

Setelah diperoleh data pendukung penelitian, maka dibuat model pendekatan berorientasi objek yaitu use case diagram.

d. Desain interface (front end) dan back end

Setelah dilakukan tahap perancangan sistem, maka dibuat desain interface - front end dan back end.

e. Penerapan metode SAW

Setelah tahap pembuatan front end dan back end, kemudian menerapkan metode SAW yang digunakan sebagai alat untuk menghitung penilaian keluarga miskin yang berhak mendapatkan bantuan.

f. Pembahasan dan hasil

Tahapan ini dilakukan pembahasan penilaian keluarga miskin dan hasil sistem yang sudah dibuat, maka di uji coba untuk menentukan keluarga miskin yang berhak mendapatkan bantuan. Seberapa besar relevansi keluarga miskin dengan kriteriakriteria keluarga miskin yang dimiliki dan seberapa besar efektifitas data yang dihasilkan oleh sistem dalam memudahkan proses penentukan keluarga miskin yang berhak mendapatkan bantuan.

\subsection{PEMODELAN FUNGSIONAL}

Alat bantu yang digunakan untuk memodelkan fungsional sistem ini adalah use case diagram. Pemodelan fungsional dibuat berdasarkan kebutuhan sistem sehingga pengambilan keputusan untuk Program Bantuan Tunai Langsung di Desa Luwungbata dan kebutuhan informasi terkait dapat terpenuhi secara efisien dan efektif. 


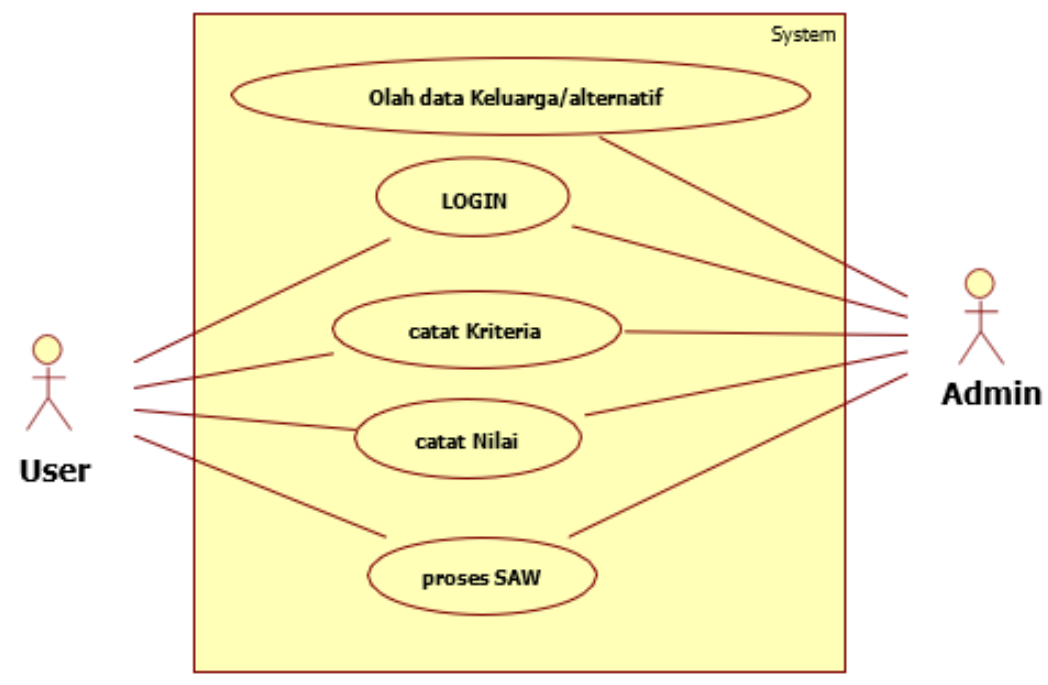

Gambar 1. System Use Case Diagram

\subsection{PENERAPAN METODE SAW}

Metode SAW membutuhkan proses normalisasi matriks keputusan ke suatu skala yang dapat diperbandingkan dengan semua rating alternatif yang ada. Data yang dibutuhkan dalam metode ini adalah alternatif keputusan, kriteria penilaian dan bobot keputusan yang mempengaruhi dalam pendukung keputusan untuk menentukan keluarga miskin yang berhak menerima bantuan langsung tunai.

Untuk mempermudah perhitungan, terlebih dahulu membuat kriteria. Kriterianya adalah sebagai berikut :
$\mathrm{C} 1=$ Luas Bangunan
$\mathrm{C} 2=$ Jenis Lantai
C3 = Jenis Dinding
C4 $=$ Fasilitas Buang Air
$\mathrm{C} 5=$ Sumber Penerangan
C6 = Bahan Bakar
C7 = Makanan Sehari-hari
C8 $=$ Pakaian
C9 = Pengobatan
$\mathrm{C} 10=$ Pendidikan berikut :

Adapun bobot dari kriteria dalam sistem pendukung keputusan ini adalah sebagai

Tabel 1. Bobot Kriteria

\begin{tabular}{|l|c|}
\hline \multicolumn{1}{|c|}{ Kriteria } & Bobot Kriteria \\
\hline Luas bangunan & 17,5 \\
\hline Jenis Lantai & 17,5 \\
\hline Jenis Dinding & 15 \\
\hline Fasilitas Buang Air & 20 \\
\hline Sumber Penerangan & 15 \\
\hline
\end{tabular}




\begin{tabular}{|l|c|}
\hline \multicolumn{1}{|c|}{ Kriteria } & Bobot Kriteria \\
\hline Bahan Bakar & 15 \\
\hline Makanan sehari-hari & 26,5 \\
\hline Pakaian & 26 \\
\hline Pengobatan & 20 \\
\hline Pendidikan & 27,5 \\
\hline
\end{tabular}

\section{PERANCANGAN DAN IMPLEMENTAI SISTEM}

Perancangan dalam pembangunan sistem informasi merupakan upaya untuk mengkonstruksi sebuah sistem yang memberikan kepuasan (mungkin informal) akan spesifikasi kebutuhan fungsional, memenuhi target, memenuhi kebutuhan secara implisit atau eksplisit dari segi performansi maupun penggunaan sumber daya, kepuasan batasan pada proses desain dari segi biaya, waktu, dan perangkat.

Hasil dari perancangan sistem pada penelitian ini adalah skema database dan desain antar muka sistem. Skema database adalah model transformasi dari pemodelan konseptual data yang dibutuhkan sistem ini. Perancangan Antarmuka dibuat mulai dari halaman awal, halaman login, halaman input sampai halaman output.

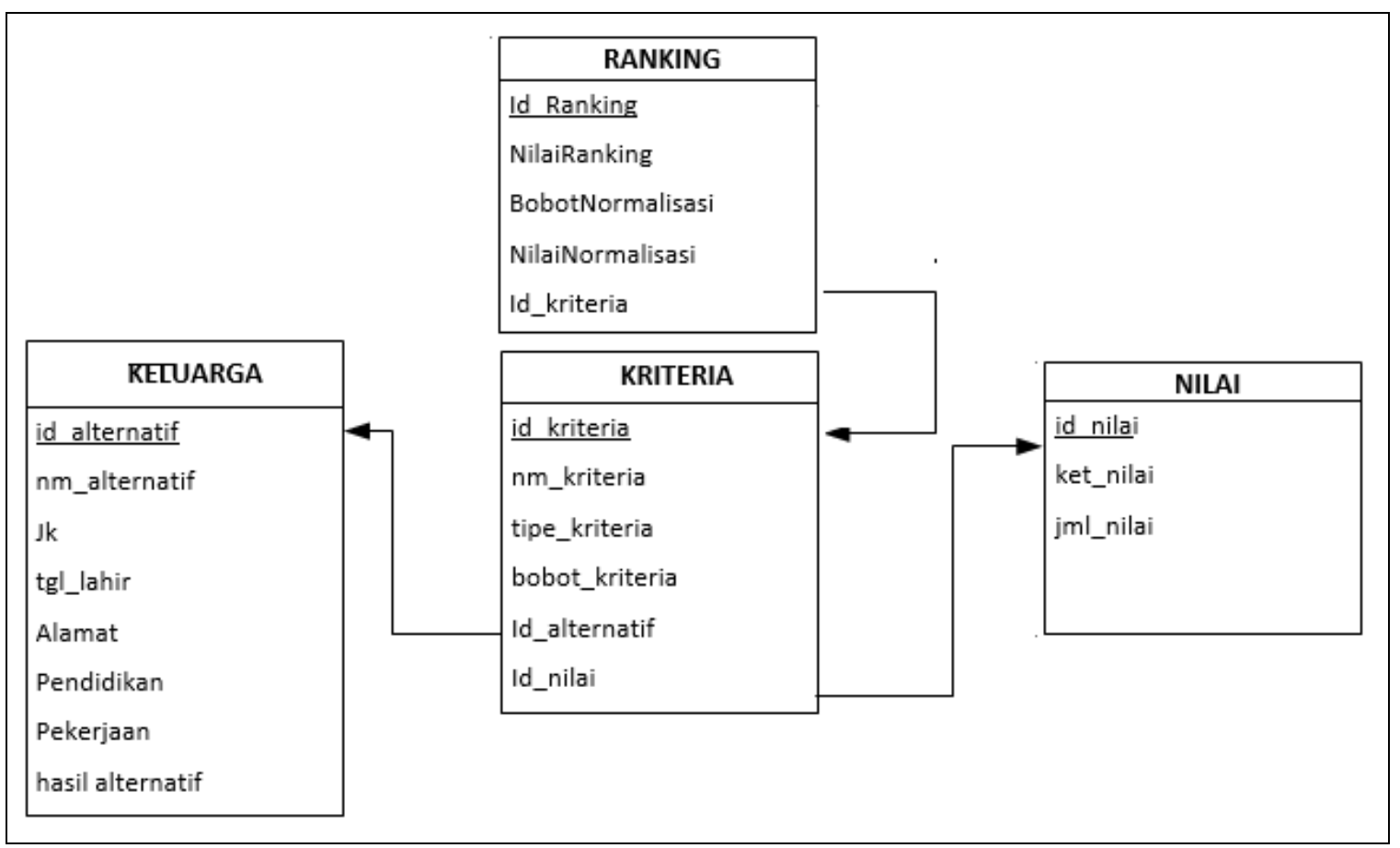

Gambar 2. Skema Database 


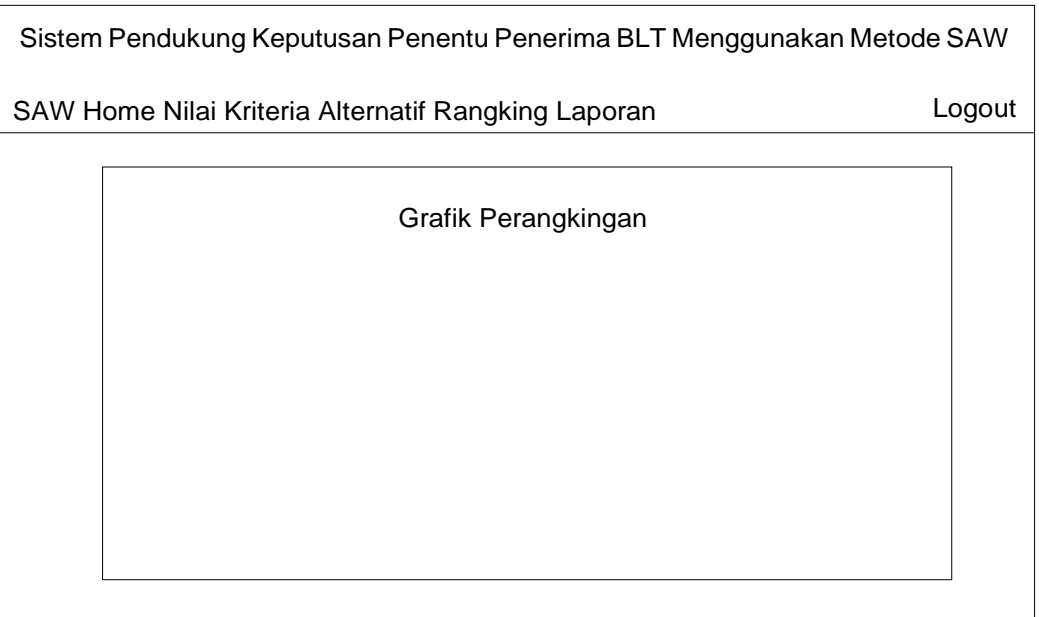

Gambar 3. Desain Halaman Utama

Sistem Pendukung Keputusan Penentu Penerima BLT Menggunakan Metode SAW
SAW Home Nilai Kriteria Alternatif Rangking Laporan Logout

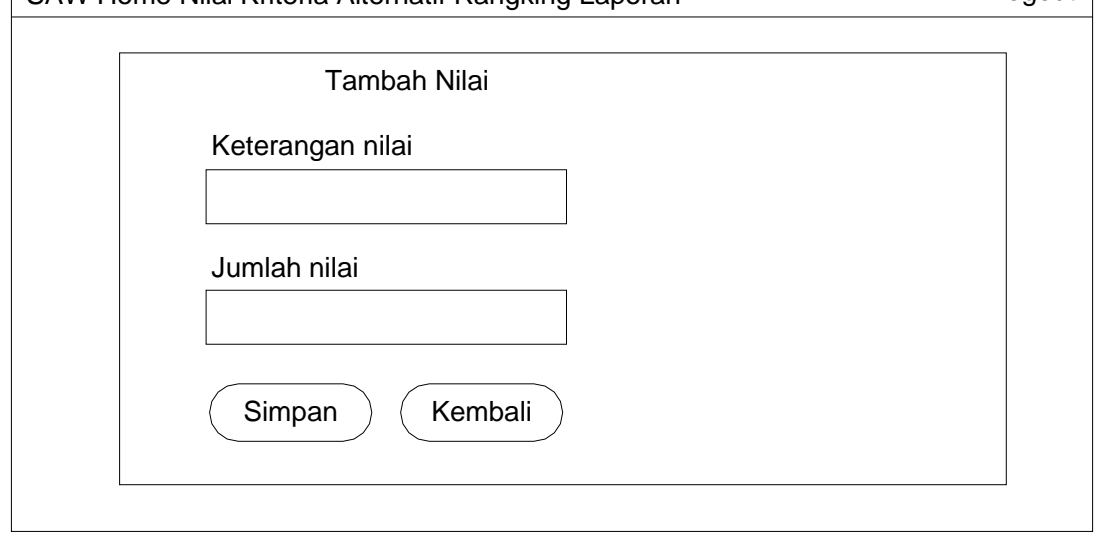

Gambar 4. Desain Form Tambah Nilai

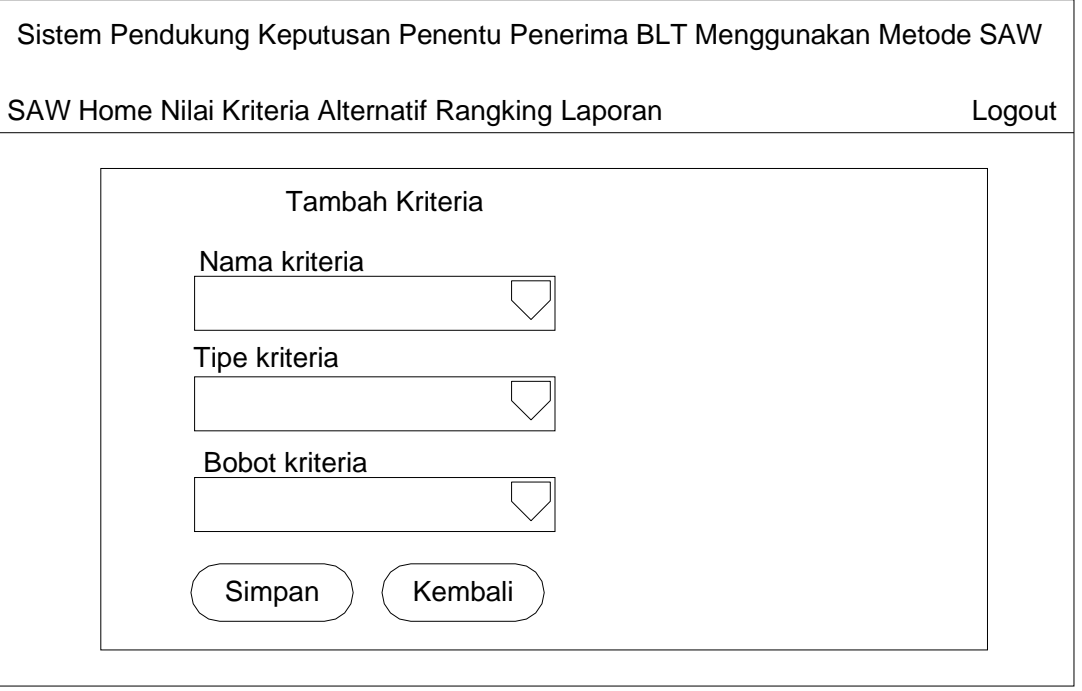

Gambar 5. Desain Form Tambah Kriteria 


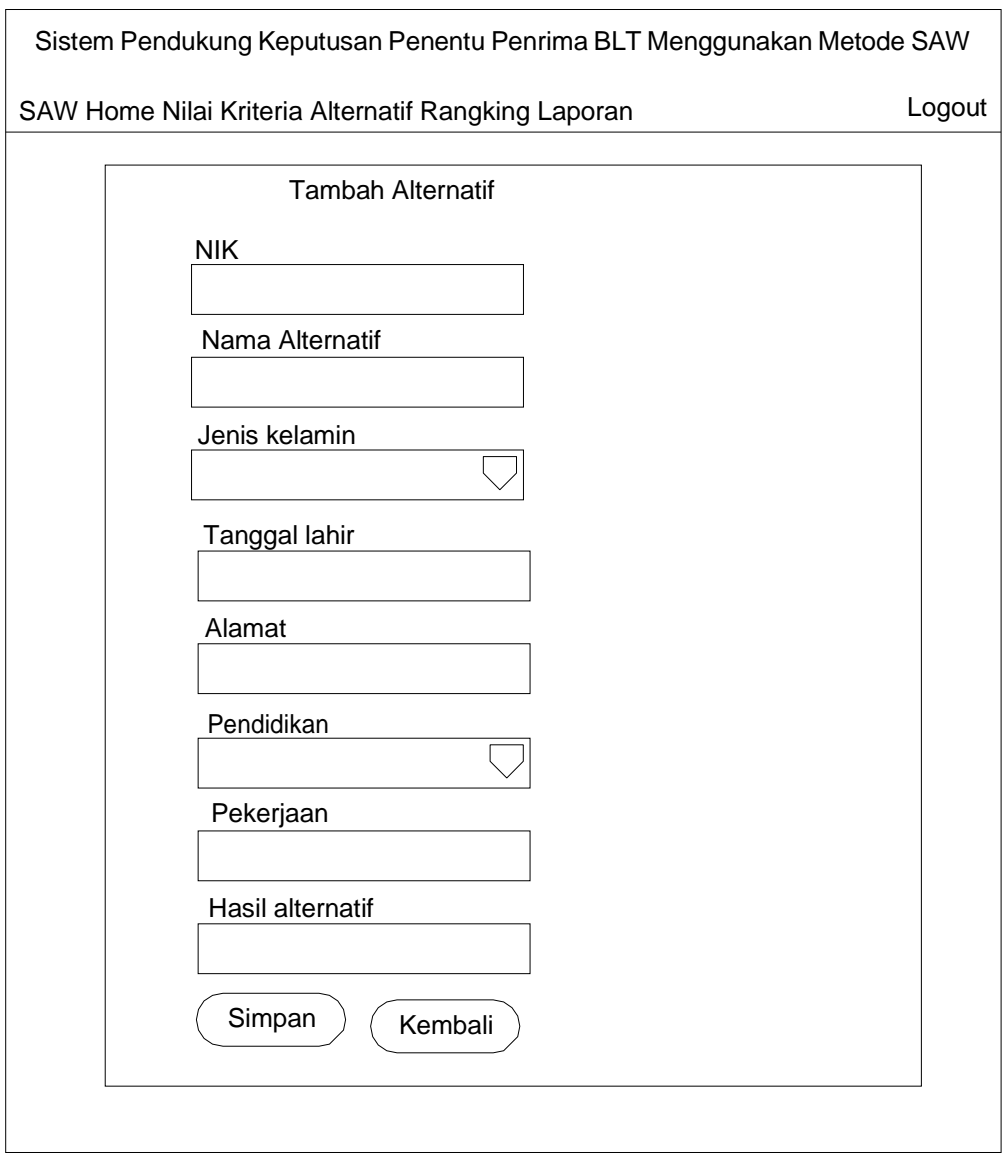

Gambar 6. Desain Form Tambah Kriteria

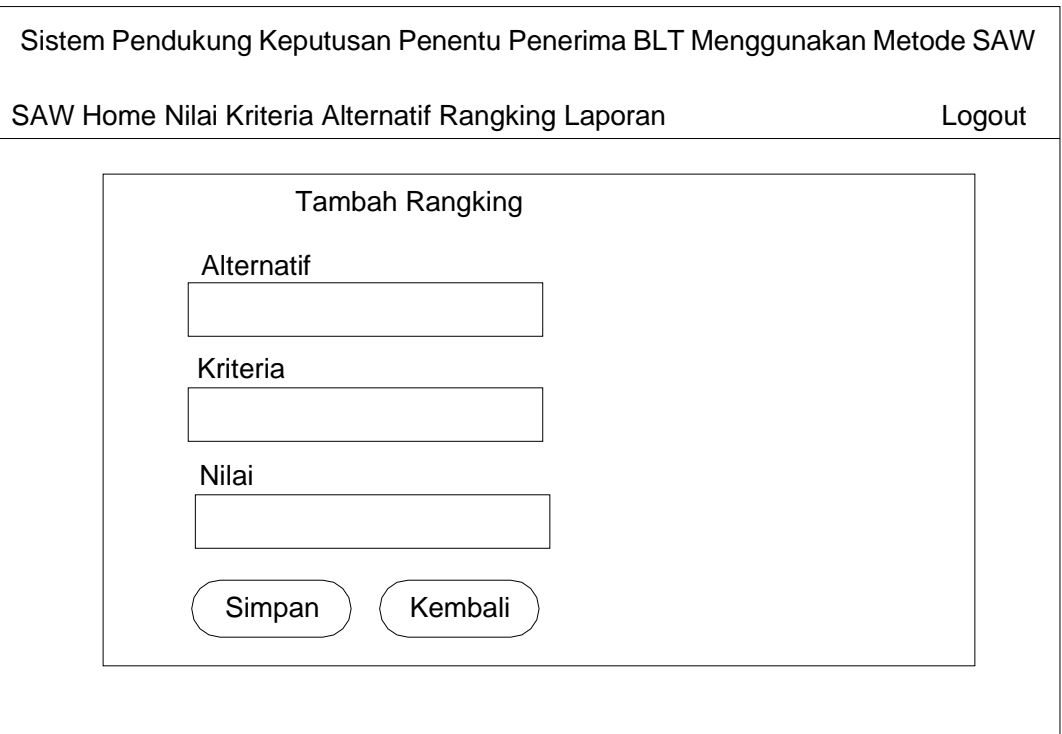

Gambar 7. Desain Form Tambang Rangking 


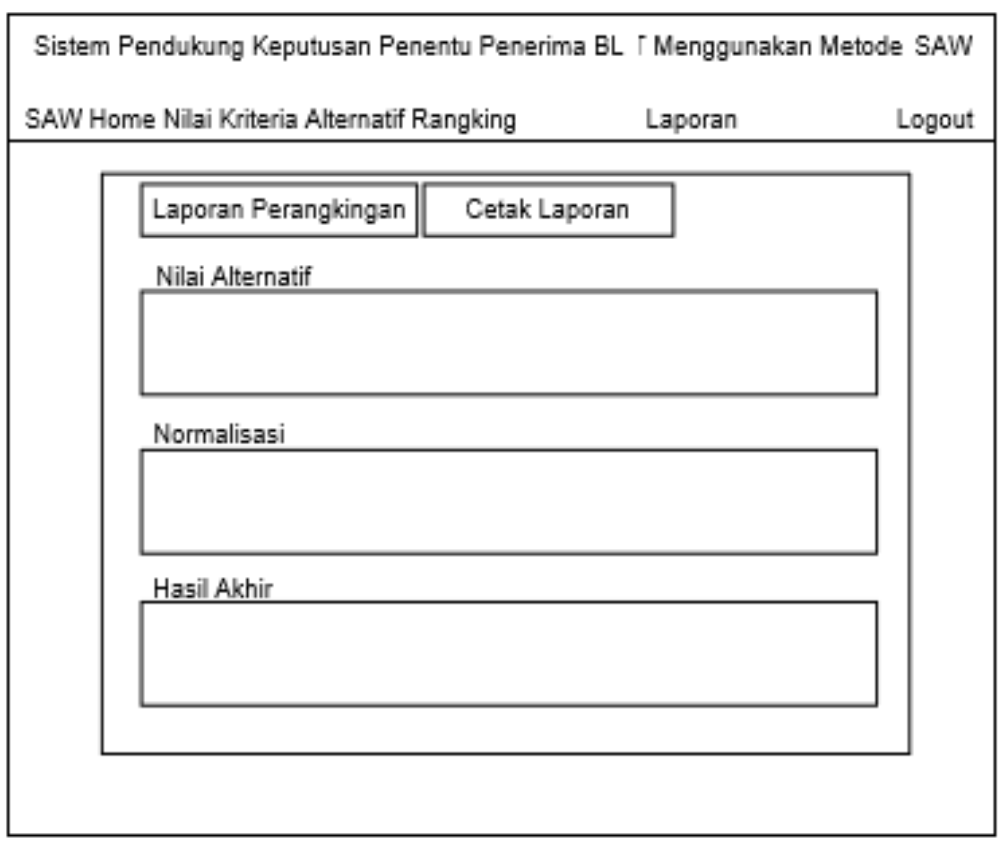

Gambar 8. Halaman Laporan

\section{KESIMPULAN}

Kesimpulan dari penelitian yang telah dilakukan mengenai SPK Simple Additive Weighting Program Bantuan Langsung Tunai di Desa Luwungbata. adalah sebagai berikut :

a. Metode Simple Additive Weighting dapat digunakan untuk mendukung pengambilan keputusan untuk Program Bantuan Langsung Tunai dengan kriteria dan bobot tertentu.

b. Sistem pendukung keputusan dengan Simple Additive Weighting dapat menentukan keluarga miskin yang lebih tepat sasaran dan lebih objektif untuk keluarga yang berhak karena proses pemilihan dilakukan secara ilmiah berdasarkan ketentuan program BLT.

\section{DAFTAR PUSTAKA}

Ananta, P. W. Menggunakan Metode Gap Kompetensi, 2013.

Dermawan, R. Pengambilan Keputusan, 2013.

Erinawati, H. D. Pembangunan Sistem Informasi Pembayaran Sekolah Pada Sekolah Menegah Atas (SMA) Negeri 1 Rembang Berbasis Web, 2012.

Farouq, K., \& Sholihin, M. Penerapan Fuzzy Tsukamoto Dalam Pengangkatan Jabatan Pegawai Di BKD Lamongan, 2014.

Fatmawati, D., Sultoni, \& Sadikin. Sistem Pengambilan Keputusan Kelayakan Bagi Calon Penerima Dana Bantuan Masyarakat Miskin Menggunakan Metode Topsis Berbasis Web, 2016.

Frieyadie. Penerapan Metode Simple Additive Weight (SAW) Dalam Sistem Pendukung Keputusan Promosi Kenaikan Jabatan, 2016.

Hartini, D. C., Ruskan, E. L., Ibrahim, A. Sistem Pendukung Keputusan Pemilihan Hotel Di Kota Palembang Dengan Metode Simple Additive Weighting (SAW), 2013.

BAPPENAS, Panduan Pendataan Bantuan Langsung Tunai-Dana Desa, 2020. 
Pressman, Roger, S. Software Engineering : A Practitioner's Approach, 7th ed., Mc Graw Hill, 2010.

Priyanti, D., \& Iriani, S. Sistem Informasi Data Penduduk Pada Desa Bogoharjo Kecamatan Ngadirojo Kabupaten Pacitan, 2013.

Riyanto, E. A., \& Haryanti, T. Sistem Pendukung Keputusan Pemilihan Teller Pooling Terbaik Pada PT . BCA Tbk . Dengan Metode SAW (Simple Additive Weighting), 2017.

Sholihin, M., Fuad, N., \& Khamiliyah, N. Sistem Pendukung Keputusan Penentuan Warga Penerima Jamkesmas Dengan Metode Fuzzy Tsukamoto, 2013.

Sodo, Robert Justin, Utari Valentina Y. D., Kajian Pelaksanaan Program Bantuan Langsung Tunai (BLT) 2008 dan Evaluasi Penerima Program BLT 2005 di Indonesia, Lembaga Penelitian SMERU, 2013

Sudarmana, L., \& Putra, W. S. A. K. Membangun Sistem Pendukung Keputusan Biro Perjalanan Haji Dan Umroh di Yogyakarta Menggunakan Metode Simple Additive Weghting, 2017.

W Wijayanti, K Kustanto, S Tomo, Sistem Pendukung Keputusan Penentuan Penerima Bantuan Langsung Tunai Di Kantor Kepala Desa Ngringo Dengan Menggunakan Algoritma Simple Additive Weighting, Jurnal Teknologi Informasi dan Komunikasi (TIKomSiN) 5 (1), 2013. 